\title{
Symposium: 2014 Bernese Hip Symposium
}

\section{Editorial Comment: Symposium: 2014 Bernese Hip Symposium}

\author{
Klaus-Arno Siebenrock MD
}

$\mathrm{T}$ here is a decades-long tradition at the University of Bern to pioneer new ideas and surgical techniques through courses and symposia. In the early years, under the guidance of Maurice E. Müller, Bernese hip courses focused on hip replacement. In time, many instructional courses were held in different languages. Gradually, the focus of these hip courses changed to jointpreserving surgery.

The newly described concept of femoroacetabular impingement (FAI), developed by Reinhold Ganz and his

The author certifies that he, or any members of his immediate family, has no funding or commercial associations (eg, consultancies, stock ownership, equity interest, patent/ licensing arrangements, etc.) that might pose a conflict of interest in connection with the submitted article.

All ICMJE Conflict of Interest Forms for authors and Clinical Orthopaedics and Related Research ${ }^{\circledR}$ editors and board members are on file with the publication and can be viewed on request.

The opinions expressed are those of the writers, and do not reflect the opinion or policy of CORR ${ }^{\circledR}$ or the Association of Bone and Joint Surgeons ${ }^{\circledR}$.

K.-A. Siebenrock MD ( $₫)$

Orthopaedic Surgery, University of Bern, Inselspital, 3010 Bern, Switzerland e-mail: klaus.siebenrock@insel.ch

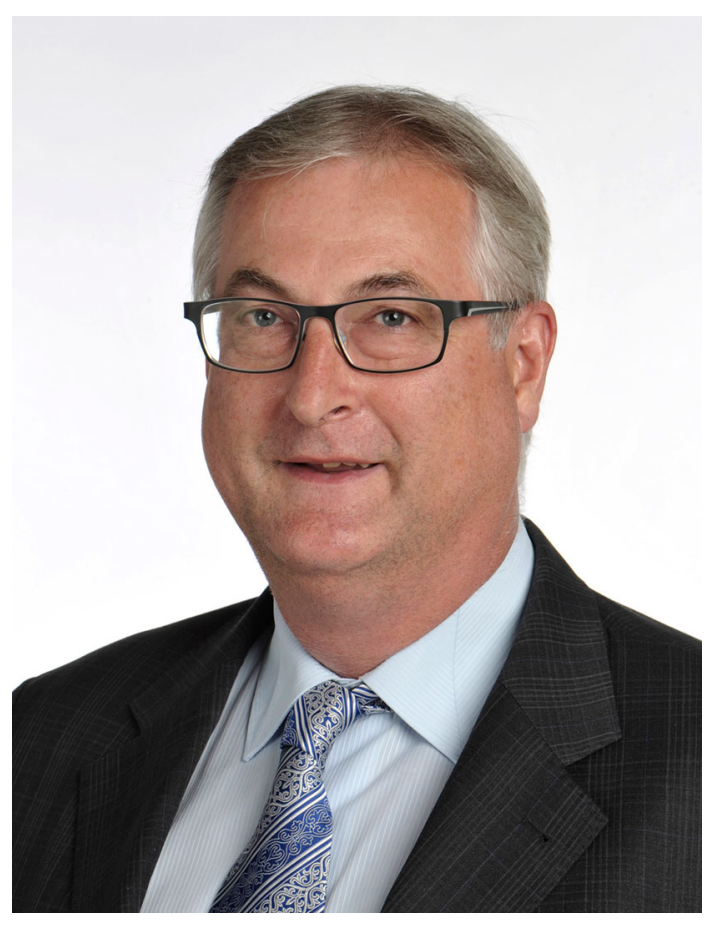

Klaus-Arno Siebenrock MD

coworkers [3] in the late 1990s, became the dominant topic at the Bernese hip course. Osteotomies around the hip, especially the periacetabular osteotomy, and the approach for a safe surgical hip dislocation [2] have made a tremendous impact on modern hip joint surgery and subsequently, these concepts have spread throughout the world.
Following in the footsteps of Professors Müller and Ganz, I have been fortunate enough to have a role to play at the program in Bern, and our group has continued to advance the science and specialty of hip-joint preservation. The analysis of the pathogenesis of hip disease [4], development of an experimental model of FAI [5] and longterm outcome studies $[1,6]$ underscore 


\section{Symposium: 2014 Bernese Hip Symposium}

the group's dedication to this field of surgery.

Hip preservation has attracted worldwide attention at an incredible speed and with frequent advances and innovations; it can be difficult for the orthopaedic community to stay abreast of the rapid developments in this field. The wide variety of surgical treatment options for the hip joint include remodeling and reorientation procedures of the acetabulum and proximal femur. This includes true neck osteotomies, head reductionplasties, capital reorientation procedures, and contouring of the acetabular rim and acetabular reorientation. Hip arthroscopy is a powerful and popular tool for remodeling procedures like head-neck offset improvement and acetabular rim trimming. The number of hip arthroscopies has grown at a tremendously fast pace-perhaps even too fast. One explanation is that hip arthroscopy is commonly regarded as a minimal invasive procedure. Because of this, many orthopaedic surgeons are tempted to perform hip arthroscopy, but typically only address the one or two most obvious abnormal findings in the hip: The cam deformity and labral lesions. However, the Bernese Hip Symposium revealed that FAI can be more complex and three-dimensional (3-D) analysis of acetabular and femoral morphology has to be taken into account, especially when considering a potential malorientation on each side of the hip. Therefore, I strongly believe that future hip joint preserving surgery should ideally be exerted by well-trained orthopaedic surgeons who are familiar with the entire spectrum of modern hip joint surgery: Safe open surgical hip dislocation and its extensions, osteotomies around the hip, and hip joint arthroscopy.

In light of these profound changes in hip joint surgery, the format of the Bernese Hip Symposium has been changed to a meeting of worldwide specialists in hip preservation. Instead of an instructional course, it is now a platform that runs every 2 years where the newest ideas and innovations are presented and are meticulously analyzed by leading experts. The $C O R R^{\circledR}$ symposium represents a platform of selected presentations and research work from the faculty of the Bernese Hip Symposium held in February 2014. The goal is to share new ideas and recent developments with the orthopaedic community, and to provide access to any orthopaedic surgeon interested in this topic. The organizers were impressed by the overwhelming contributions and commitment of the entire faculty of the Bernese Hip Symposium.

The Symposium was held from February 6 to 8, 2014. It covered a large range of topics including ontogenesis, modern imaging modalities and 3-Dbased analysis of pathomorphologies, long-term followup studies, and complex surgical techniques for correction of hip joint deformities.

In the past decade, treatment options for deformities around the hip joint have expanded. In addition to the development of improved techniques for hip arthroscopy, the extension of the technique of safe surgical dislocation has opened new possibilities to correct complex deformities of the hip joint like the sequelae of Perthes disease or complex developmental dysplasia of the hip. The symposium allows experts to share the benefits and drawbacks of these extremely complex surgeries.

It has become clear that the expertise and dedication of outstanding leaders in hip preservation is essential in this wide-open and controversial field. Professionalism and honest presentation of favorable outcomes-as well as pitfalls and failures-are the keys for a successful symposium and ultimately to the benefit of our patients. The tremendous scientific output of this Symposium was rewarding to all who 


\section{Symposium: 2014 Bernese Hip Symposium}

contributed and will inspire the faculty to look forward to the next meeting in March 2016.

\section{References}

1. Albers CE, Steppacher SD, Ganz R, Tannast M, Siebenrock KA. Impingement adversely affects 10-year survivorship after periacetabular osteotomy for DDH. Clin Orthop Relat Res. 2013;471:1602-1614.
2. Ganz R, Gill TJ, Gutier E, Ganz K, Krügel N, Berlemann U. Surgical dislocation of the adult hip-a technique with full access to the femoral head and acetabulum without the risk of avascular necrosis. $J$ Bone Joint Surg Br. 2001;83: 119-224.

3. Ganz R, Parvizi J, Beck M, Leunig M, Nötzli H, Siebenrock KA. Femoroacetabular impingement: A cause of osteoarthritis of the hip. Clin Orthop Relat Res. 2003;417:112-120.

4. Siebenrock KA, Ferner F, Noble PC, Santore RF, Werlen S, Mamisch TC.
The cam-type deformity of the proximal femur arises in childhood in response to vigorous sporting activity. Clin Orthop Relat Res. 2011;469: 32290-322940.

5. Siebenrock KA, Fiechter R, Tannast M, Mamisch TC, von Rechenberg B. Experimentally induced cam impingement in the sheep. J Orthop Res. 2013;4:580-587.

6. Steppacher SD, Tannast M, Ganz R, Siebenrock KA. Mean 20-year follow-up of Bernese periacetabular osteotomy. Clin Orthop Relat Res. 2008;466:1633-1644. 